\title{
Von Hippel-Lindau regulates interleukin-32 $\beta$ stability in ovarian cancer cells
}

\author{
Hyo Jeong Yong ${ }^{1}$, Jeong Su Park ${ }^{2}$, Ae Lee Jeong ${ }^{1}$, Sora Han ${ }^{1}$, Sunyi Lee ${ }^{1}$, Hye \\ In Ka ${ }^{1}$, Buyanravjkh Sumiyasuren ${ }^{1}$, Hyun Jeong Joo ${ }^{1}$, Su Jeong So ${ }^{1}$, Ji Young Park ${ }^{1}$, \\ Do-Young Yoon ${ }^{3}$, Jong-Seok Lim ${ }^{1}$, Myeong-Seok Lee ${ }^{1}$, Hee Gu Lee ${ }^{4}$ and Young \\ Yang $^{1}$ \\ ${ }^{1}$ Department of Biological Sciences, Sookmyung Women's University, Seoul, Republic of Korea \\ ${ }^{2}$ Department of Severance Biomedical Science Institute, Yonsei Biomedical Research Institute, Yonsei University College of \\ Medicine, Seoul, Korea \\ ${ }^{3}$ Department of Bioscience and Biotechnology, Bio/Molecular Informatics Center, Konkuk University, Seoul, Republic of Korea \\ ${ }^{4}$ Immunotherapy Convergence Research Center, Korea Research Institute of Bioscience and Biotechnology, Daejeon, Republic \\ of Korea
}

Correspondence to: Young Yang, email: yyang@sm.ac.kr

Keywords: interleukin-32, von Hippel-Lindau, protein kinase C, hypoxia, apoptosis

Received: March 29, $2017 \quad$ Accepted: June 12, $2017 \quad$ Published: July 17, 2017

Copyright: Yong et al. This is an open-access article distributed under the terms of the Creative Commons Attribution License 3.0 (CC BY 3.0), which permits unrestricted use, distribution, and reproduction in any medium, provided the original author and source are credited.

\section{ABSTRACT}

Hypoxia-induced interleukin-32 $\beta$ (IL-32 $\beta$ ) shifts the metabolic program to the enhanced glycolytic pathway. In the present study, the underlying mechanism by which hypoxia-induced IL-32 $\beta$ stability is regulated was investigated in ovarian cancer cells. IL-32 $\beta$ expression increased under hypoxic conditions in ovarian cancer cells as it did in breast cancer cells. The amount of IL-32 $\beta$ was regulated by post-translational control rather than by transcriptional activation. Under normoxic conditions, IL$32 \beta$ was continuously eliminated through ubiquitin-dependent degradation by the von-Hippel Lindau (VHL) E3 ligase complex. Oxygen deficiency or reactive oxygen species (ROS) disrupted the interaction between IL-32 $\beta$ and VHL, leading to the accumulation of the cytokine. The fact that IL-32 $\beta$ is regulated by the energyconsuming ubiquitination system implies that it plays an important role in oxidative stress. We found that IL-32 $\beta$ reduced protein kinase $C \delta$ (PKC $\delta$ )-induced apoptosis under oxidative stress. This implies that the hypoxia- and ROS-stabilized IL-32 $\beta$ contributes to sustain survival against PKCס-induced apoptosis.

\section{INTRODUCTION}

Interleukin-32 (IL-32) was originally identified as a secretory protein that enhances the production of proinflammatory cytokines, including IL-1, IL-6, and tumor necrosis factor $\alpha$ (TNF- $\alpha$ ). Later, it was unveiled that IL-32 exists intracellularly in nonimmune cells such as epithelial and tumor cells [1-3]. IL-32 has nine isoforms that are generated by the alternative splicing of seven exons [4]. Functional studies of IL-32 in cancer cells have focused mainly on the IL-32 $\alpha$, IL-32 $\beta$, and IL- $32 \gamma$ isoforms because of their abundance [5]. IL-32 $\alpha$ and IL-32 $\beta$ are highly expressed in gastric, lung, pancreatic, breast, brain, and liver tumors [6-8], but they show context-dependent function in different tumors. For example, IL-32 $\alpha$ shows anti-proliferative effects in human colon cancer cells [911], whereas it enhances migration in human melanoma cells through the downregulation of E-cadherin [12] and promotes proliferation in pancreatic cells [6]. In addition, IL-32 $\beta$ is positively correlated with tumor size, number of lymph node metastases and tumor stage in primary breast cancer tissues; increases migration and invasion through signal transducer and activator of transcription 3 (STAT3) activation; and enhances glycolysis in human 
breast cancer cells $[13,14]$. On the other hand, it shows anti-tumor activity through the activation of lymphocytes including cytotoxic $\mathrm{T}(\mathrm{CD} 8+)$ and natural killer (NK) cells, and inactivation of the nuclear factor- $\mathrm{\kappa B}(\mathrm{NF}-\mathrm{\kappa B})$ and STAT3 signaling pathways [15].

The von Hippel-Lindau (VHL) tumor suppressor protein is an E3 ligase that ubiquitinates hypoxia-inducible factor- $1 \alpha(\mathrm{HIF}-1 \alpha)$ and causes its degradation by the proteasome $[16,17]$. When oxygen is abundant, VHL binds to HIF- $1 \alpha$ by recognizing its two post-translationally hydroxylated proline residues (P402 and P564) [18]. On the other hand, a lack of oxygen due to the rapidly growing tumor mass cause the inactivation of prolyl hydroxylase (PHD) preventing VHL from recognizing and binding to HIF- $1 \alpha$ and thus leading to HIF- $1 \alpha$ accumulation, which induces the transcription of genes involved in adaptation to hypoxia $[19,20]$. In addition to prolyl hydroxylation, asparaginyl hydroxylation has also been identified as an oxygen-regulated signal that determines the stability of HIF- $1 \alpha$. Both reactions are catalyzed by members of the 2-oxoglutarate (2OG)-dependent oxygenase superfamily: HIF- $1 \alpha$ prolyl hydroxylation by PHD domains $1-3$, and HIF- $1 \alpha$ asparaginyl hydroxylation by factor inhibiting HIF-1 $\alpha$ (FIH). Since hydroxylation is one of the important post-translational modifications, the assignment of molecular functions for all human 2OG oxygenases by combined biochemical and cellular approaches is required. As an effort, accumulating data on newly identified hydroxylated proteins are expanding [21,22].

The protein kinase C (PKC) family comprises serine/threonine kinases that regulate a diverse set of cellular processes including proliferation, apoptosis, survival, and migration, and there is a substantial amount of evidence linking PKC to tumorigenesis [23]. According to their domain structure and respective activators, they have been divided into three major groups: the classical PKCs, including the $\alpha, \beta I, \beta I I$, and $\gamma$ isoforms; the novel PKCs, including the $\theta, \eta, \varepsilon$, and $\delta$ isoforms; and the atypical PKCs, including $\zeta$ and $1 / \lambda$ [24]. Among various isoforms of $\mathrm{PKC}, \mathrm{PKC} \varepsilon$ and $\mathrm{PKC} \delta$ have opposing roles in regulating apoptosis, survival and proliferation. PKC $\varepsilon$ promotes cell survival in many cell types, whereas $\mathrm{PKC} \delta$ performs a growth inhibitory or pro-apoptotic role [23, 24]. When PKC $\delta$ is activated by oxidative and hypoxic stress, $\mathrm{PKC} \delta$ forms complex with $\mathrm{Abl}$ in the endoplasmic reticulum (ER), and then $\mathrm{PKC} \delta$-Abl complex translocates from ER to the mitochondria, leading to caspase-3 cleavage and cytochrome c release to trigger apoptosis [24-26]. The functional connection between IL-32 $\beta$ and $\mathrm{PKC} \delta$ has recently been unveiled by the report that IL-32 $\beta$ upregulates IL-10 production through its association with PKC $\delta$ around the nuclear membrane [27, 28].

In the present study, we investigated the function of IL-32 $\beta$ in human ovarian cancer cells which is one of the representative female cancers. Our results revealed that IL-32 $\beta$ is degraded by VHL-mediated ubiquitination, a process that is prevented by hypoxia-induced reactive oxygen species (ROS) production. $\mathrm{PKC} \delta$ forms trimers with IL-32 $\beta$ and VHL. Under hypoxic conditions, the interaction between IL-32 $\beta$ and PKC $\delta$ is sustained, whereas that with VHL is disrupted. In turn, the increased IL-32 $\beta$ level reduces PKC $\delta$-mediated apoptosis under oxidative stress.

\section{RESULTS}

\section{IL-32 $\beta$ level increases under hypoxic conditions in ovarian cancer cells}

We had previously shown that IL-32 $\beta$ level is increased and enhances glycolysis in breast cancer cells to survive under hypoxic conditions [14]. In the present study, we determined the molecular mechanism by which IL-32 $\beta$ stability is increased under hypoxic conditions in ovarian cancer cells. The levels of IL-32 protein and mRNA were examined in three different human ovarian cancer cell lines: IGROV1, SKOV3, and OVCAR8 cells. Although IGROV1 cells expressed both IL-32 $\beta$ and IL$32 \gamma$ mRNA, the proteins were not detected, even with longer exposure. SKOV3 cells showed lower levels of IL-32 $\beta$ and IL-32 $\gamma$ mRNA expression than OVCAR8 cells. On the other hand, the IL-32 $\beta$ and IL- $32 \delta$ proteins were highly expressed in OVCAR8 cells (Figure 1A). To determine whether IL-32 $\beta$ expression is increased by hypoxic conditions, the ovarian cancer cells were treated with $\mathrm{CoCl}_{2}$, a hypoxia mimetic chemical. Whereas vascular endothelial growth factor (VEGF) mRNA expression (as a positive control) was markedly increased in all three cell lines, IL-32 $\beta$ mRNA expression was only modestly increased in SKOV3 and OVCAR8 cells (Figure 1B). However, the IL-32 $\beta$ protein was highly increased in SKOV3 and OVCAR8 cells $3 \mathrm{~h}$ after $\mathrm{CoCl}_{2}$ treatment, but IL-32 $\beta$ proteins were not detected even in the ROS-stimulated in IGROV1 cells (Figure 1C). One possibility is that IGROV1 cells may have epigenetically suppressed IL-32 $\beta$. Thus, we determined whether IL-32 $\beta$ translation was increased. When cells were co-treated with cyclohexamide $(\mathrm{CHX})$ and $\mathrm{CoCl}_{2}$ for the indicated time intervals, the $\mathrm{CoCl}_{2}$-induced increase in IL-32 $\beta$ level was not observed (Figure 1D). If IL-32 $\beta$ is regulated by proteasomal degradation, the pre-existing IL- $32 \beta$ should be detected after the CHX treatment. However, if the steady state level of IL-32 $\beta$ is very low, it is possible that IL-32 $\beta$ level is low in the presence of CHX.

\section{Hypoxic conditions inhibit IL-32 $\beta$ degradation}

There are two mechanisms to explain the increase of protein amount: increase of the translation rate, and inhibition of protein degradation. To examine the possibility of proteasomal degradation, SKOV3 and OVCAR8 cells were treated with MG-132 for the 
indicated time intervals. IL-32 $\beta$ was clearly increased $3 \mathrm{~h}$ after the treatment (Figure 2A). However, when cells were treated with pepstatin $\mathrm{A}$, an inhibitor of lysosomal degradation, the increase in IL-32 $\beta$ level was not observed (Figure 2B). These results imply that the translated IL-32 $\beta$ had been continuously degraded by ubiquitination. In the previous study, we showed that the $\mathrm{CoCl}_{2}$-induced increase in IL-32 $\beta$ level was mediated by ROS production in breast cancer cells. The ovarian cancer cells also showed the $\mathrm{CoCl}_{2}$-mediated increase in IL-32 $\beta$ production, which was prevented by treatment with $\mathrm{N}$-acetyl-cysteine (NAC), an anti-ROS reagent, in a dose-dependent manner (Figure 2C), and co-treatment of MG-132 with NAC reverse the latter's effect (Figure
2D). This implies that ROS stabilize IL-32 $\beta$ levels through the inhibition of proteasomal degradation. To further confirm that IL-32 $\beta$ is continuously degraded under normal conditions, we examined whether it is ubiquitinated. Cells were transfected with Myc-IL-32 $\beta$ and Hemagglutinin (HA)-ubiquitin ( $\mathrm{Ub}$ ) and then treated with $\mathrm{CoCl}_{2}$ or MG-132. IL-32 $\beta$ was immunoprecipitated with anti-Myc antibody and immunoblotted with anti-HA antibody to examine whether IL-32 $\beta$ is ubiquitinated. MG-132 treatment increased the level of ubiquitinated IL-32 $\beta$, whereas $\mathrm{CoCl}_{2}$ treatment inhibited it (Figure 2E). Collectively, these results imply that hypoxia-induced ROS production increases IL-32 $\beta$ levels by preventing its ubiquitination.

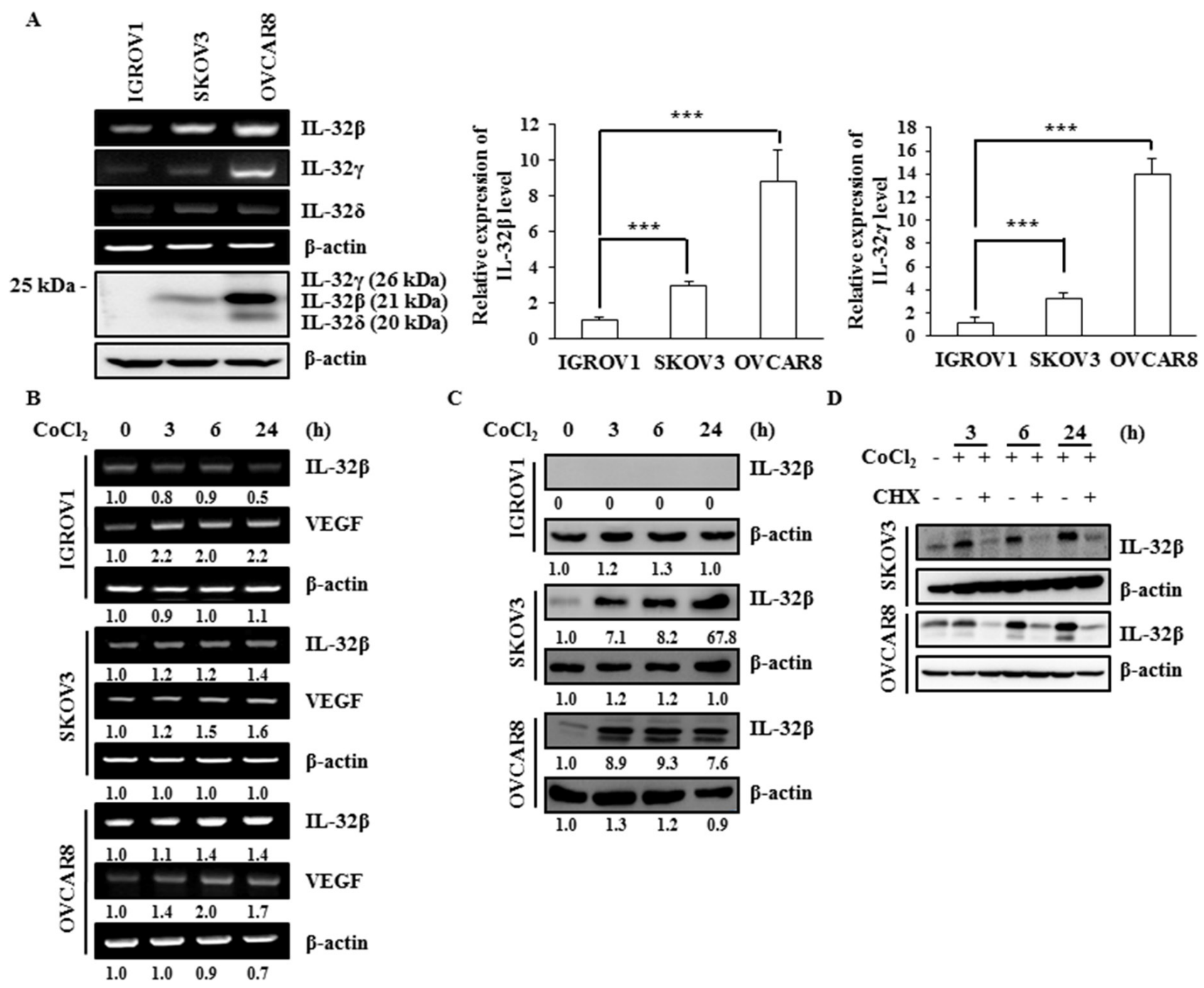

Figure 1: IL-32 $\beta$ levels increase under hypoxic conditions in ovarian cancer cells. (A) The IL-32 levels in the human ovarian cancer cell lines IGROV1, SKOV3, and OVCAR8 were determined by RT-PCR, qRT-PCR, and immunoblot assays. The qRT-PCR results were normalized with the level of IL-32 $\beta$ and IL-32 $\gamma$ in IGROV1 cells, respectively. The data shown represent one of three independent experiments carried out in triplicate. (B, C) SKOV3 and OVCAR8 cells were treated with $150 \mu \mathrm{M} \mathrm{CoCl}_{2}$ and the IL-32 $\beta$ levels were determined by RT-PCR and immunoblot assays at the indicated times. The bands were quantified using ImageJ software and the numbers indicate the comparison of each lane. (D) SKOV3 and OVCAR8 cells were treated with $150 \mu \mathrm{M} \mathrm{CoCl}_{2}$ and $5 \mu \mathrm{g} / \mathrm{mL} \mathrm{CHX}$. The IL-32 $\beta$ levels were determined by immunoblot assay at the indicated times. 
The VHL E3 ligase complex is responsible for IL-32 $\beta$ degradation

VHL is a well-known E3 ligase involved in HIF$1 \alpha$ degradation under normoxic conditions. Kelchlike ECH-associated protein 1 (Keap1) is also an E3 ligase involved in nuclear factor erythroid 2-related factor 2 (Nrf-2) degradation in the absence of ROS, and Carboxyl terminus of HSP70-interacting protein (CHIP) is a chaperone-dependent E3 ligase that ubiquitylates unfolded protein under ROS stress [29-32]. To find out which E3 ligase is responsible for IL-32 $\beta$ ubiquitination,

A

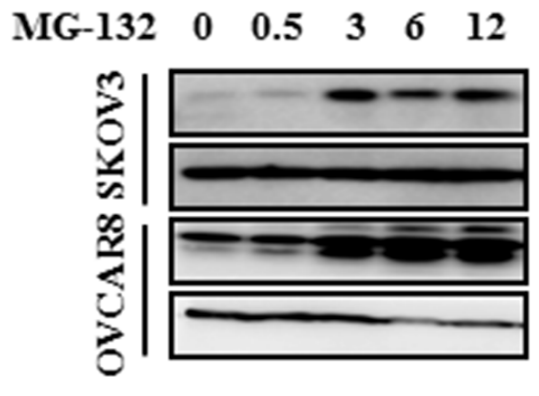

(h)

IL-32 $\beta$

$\beta$-actin

IL-32 $\beta$

$\beta$-actin

C

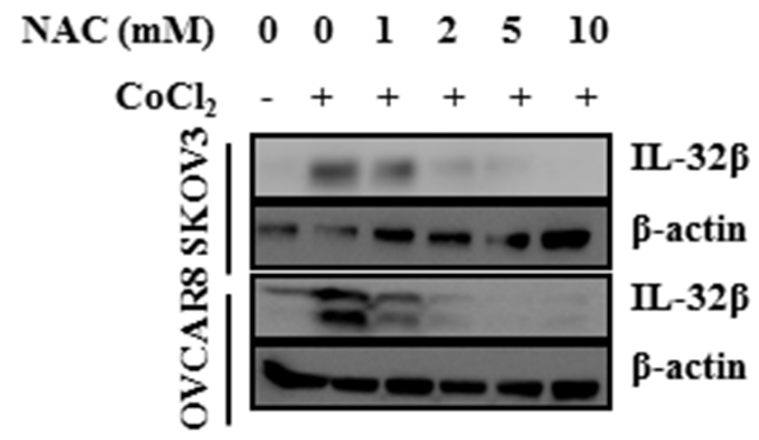

D

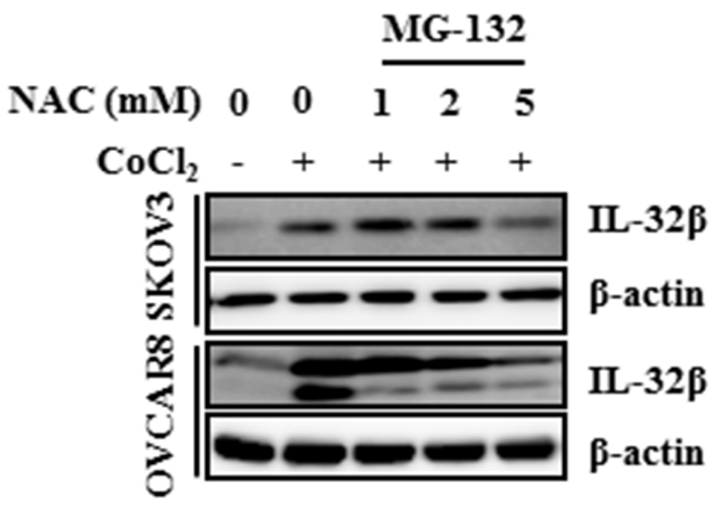

SKOV3 and OVCAR8 cells were transfected with VHL small interfering RNA (siRNA), CHIP siRNA, and Keap1 siRNA. The IL-32 $\beta$ was increased after VHL siRNA transfection (Figure 3A). To further confirm this, SKOV3 cells were induced to express IL-32 $\beta$ and HAVHL, whereupon the IL-32 $\beta$ levels were decreased by HA-VHL in a dose-dependent manner (Figure 3B). Next, OVCAR8 cells highly expressing IL-32 $\beta$ were transfected with increasing amounts of HA-VHL, whereupon the endogenous IL-32 $\beta$ decreased (Figure $3 \mathrm{C}$ ). These results imply that VHL is the E3 ligase responsible for IL-32 $\beta$ ubiquitination.
B

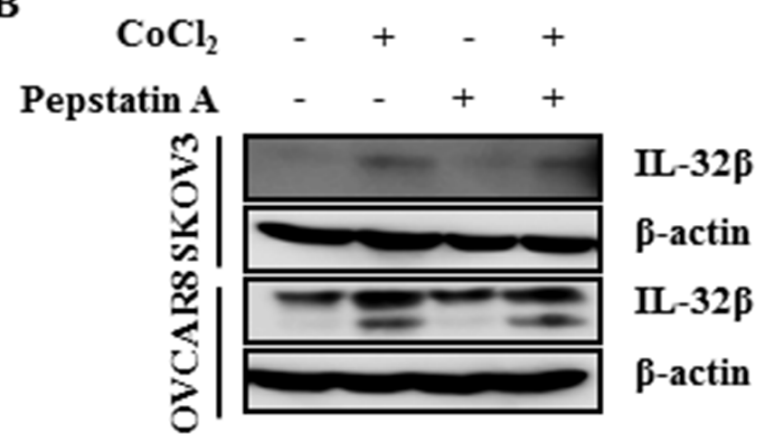

E

$\begin{array}{rrrrrr}\mathrm{Myc}-\mathrm{IL}-32 \beta & + & + & + & + & + \\ \mathrm{HA}-U b & - & + & + & + & + \\ \mathrm{CoCl}_{2} & - & - & - & + & + \\ \mathrm{MG-132} & - & - & + & + & -\end{array}$

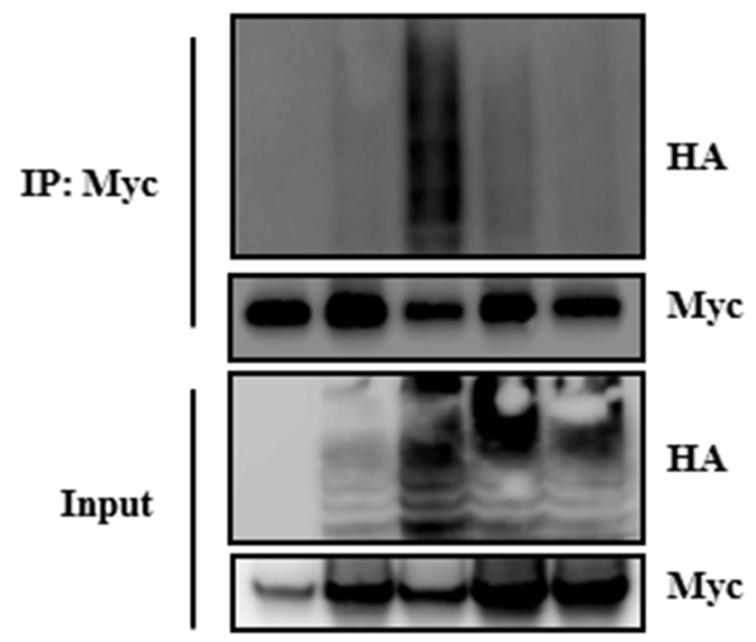

Figure 2: ROS inhibit ubiquitin-dependent IL-32 $\beta$ degradation. (A) SKOV3 and OVCAR8 cells were treated with $5 \mu$ M MG132 and the IL-32 $\beta$ levels were determined by immunoblot assay at the indicated times. (B) SKOV3 and OVCAR8 cells were pretreated with $1 \mu \mathrm{g} / \mathrm{mL}$ pepstatin A for $1 \mathrm{~h}$, and then treated with $150 \mu \mathrm{M} \mathrm{CoCl}_{2}$. (C) SKOV3 and OVCAR8 cells were pretreated with NAC for $1 \mathrm{~h}$, and then treated with $150 \mu \mathrm{M} \mathrm{CoCl}_{2}$. (D) SKOV3 and OVCAR8 cells were pretreated with NAC for $1 \mathrm{~h}$, and then treated with $150 \mu \mathrm{M} \mathrm{CoCl}_{2}$ and MG-132. (E) HEK 293T cells were transfected with Myc-IL-32 $\beta$ and HA-Ub, and then treated with $150 \mu \mathrm{M} \mathrm{CoCl}_{2}$ or $5 \mu \mathrm{M} \mathrm{MG}-132$. The cell lysates were immunoprecipitated with anti-Myc antibody and the interaction was examined by immunoblot assay. 


\section{ROS disrupt the interaction between VHL and the exon 7 coding region of IL-32 $\beta$}

To investigate the underlying molecular mechanisms by which IL-32 $\beta$ is regulated by VHL E3 ligase, cells were induced to express Myc-IL-32 $\beta$ and HA-VHL and then treated with $\mathrm{H}_{2} \mathrm{O}_{2}$. The immunoprecipitation assay revealed that the VHL and IL- $32 \beta$ interaction was disrupted after $\mathrm{H}_{2} \mathrm{O}_{2}$ treatment (Figure 4A), implying that IL-32 $\beta$ is degraded by VHL-mediated ubiquitination and this degradation is prevented by hypoxia-induced ROS production. To determine which domain of IL-32 binds to VHL, the interaction between different IL-32 isoforms and VHL was examined. All isoforms of IL-32 [33] bound to VHL (Figure 4B). Since only the exon 7-coded region is common to all isoforms of IL-32, it was the only regions shown to interact with VHL (Figure 4C). To determine which domain of VHL binds to IL-32 $\beta$, the interaction between IL-32 $\beta$ and VHL domain using VHL19, which is absent in the acidic domain of first 53 amino acid residues [34], was examined. The interaction between IL-32 $\beta$ and

A

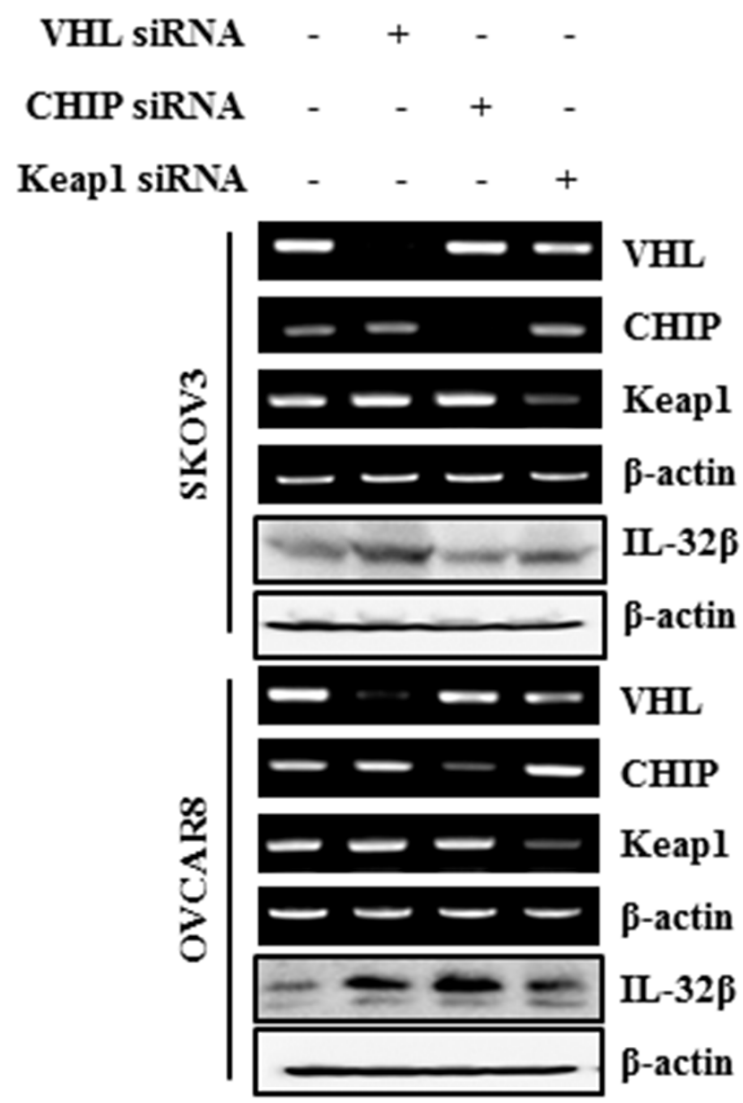

VHL19 was increased after $\mathrm{H}_{2} \mathrm{O}_{2}$ treatment, implying that acidic domain of VHL may play an important role in disruption of the interaction between IL-32 $\beta$ and VHL under hypoxic conditions (Figure 4D).

Next, we examined whether a proline residue of IL-32 $\beta$ is hydroxylated by PHD, since VHL binds only to such proline residues in HIF-1 $\alpha[19,20]$. SKOV3 and OVCAR8 cells were treated with a PHD inhibitor, dimethyloxaloylglycine (DMOG) or desferrioxamine (DFO), and IL-32 $\beta$ expression was measured. Contrary to our expectation, DMOG and DFO did not affect the IL-32 $\beta$ level in OVCAR8 cells, although SKOV3 cells showed increase in IL-32 $\beta$ level (Figure 4E, 4F). In addition, SKOV3 and OVCAR8 cells were also transfected with PHD2 siRNA and the IL-32 $\beta$ was examined. No difference was observed (Figure $4 \mathrm{G}$ ). To further confirm this result, we examined the interaction of IL-32 $\beta$ with VHL mutants that are not able to bind to hydroxyl proline residues of HIF-1 $\alpha[19,34]$. All VHL mutants still bound to IL-32 $\beta$ (Figure $4 \mathrm{H}$ ), implying that the interaction between IL-32 $\beta$ and VHL is not dependent upon proline hydroxylation.

B

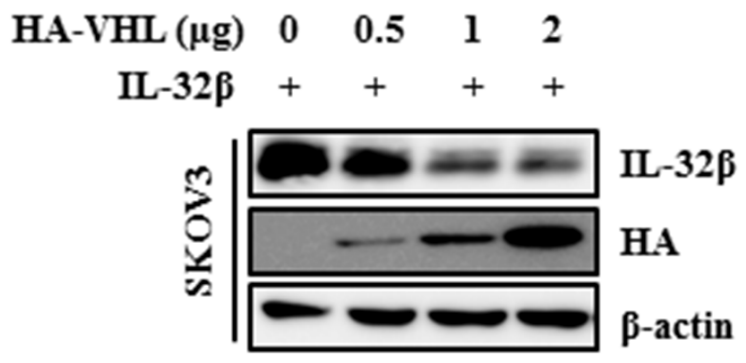

C

HA-VHL $(\mu \mathrm{g}) \quad 0 \quad 0.25 \quad 0.5 \quad 1$

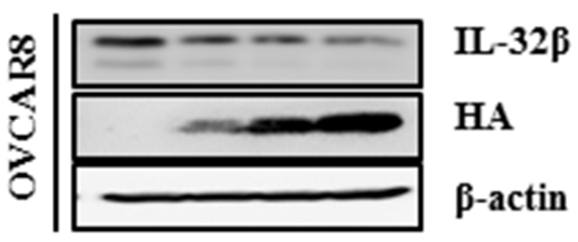

Figure 3: IL-32ß is regulated by E3 ligase VHL. (A) SKOV3 and OVCAR8 cells were transfected with VHL siRNA, CHIP siRNA, and Keap1 siRNA. The VHL, CHIP and Keap1 levels were determined by RT-PCR. The IL-32 $\beta$ levels were determined by immunoblot assay. (B) SKOV3 cells were co-transfected with IL-32 $\beta$ and HA-VHL-expressing plasmids. The IL-32 $\beta$ and VHL levels were determined by immunoblot assay. (C) OVCAR8 cells were transfected with HA-VHL. The IL-32 $\beta$ and VHL levels were determined by immunoblot assay. 


\section{PKC $\delta$ is associated with the interaction between IL-32 $\beta$ and VHL}

Since it is known that ROS activates PKC, which can interact with IL-32 and VHL [27, 35-37], PKC was examined for its possible association with the interaction between IL-32 $\beta$ and VHL. Cells were induced to express HA-VHL, Myc-IL-32 $\beta$ and Flag-PKC $\delta$, and then immunoprecipitated with anti-Flag antibody. $\mathrm{PKC} \delta$ precipitated with Myc-IL-32 $\beta$ and HA-VHL (Figure $5 \mathrm{~A})$. In addition, when cells were placed in the hypoxic chamber, the co-immunoprecipitation of IL-32 $\beta$ and
PKC $\delta$ with VHL was reduced (Figure 5B). These results imply that the interaction of VHL with either IL-32 $\beta$ or $\mathrm{PKC} \delta$ is reduced under hypoxia. However, the interaction between IL-32 $\beta$ and PKC $\delta$ was constant regardless of the oxygen conditions (Figure 5C). To further confirm this interaction in human ovarian cancer cells, OVCAR8 cells were induced to express HA-VHL, Myc-IL-32 $\beta$ and Flag-PKC $\delta$, and then immunoprecipitated with anti-HA antibody. VHL precipitated with Myc-IL-32 $\beta$ and Flag$\mathrm{PKC} \delta$. In addition, when cells were treated with $\mathrm{CoCl}_{2}$, the co-immunoprecipitation of IL-32 $\beta$ and PKC $\delta$ with VHL was reduced (Figure 5D). These results collectively
A

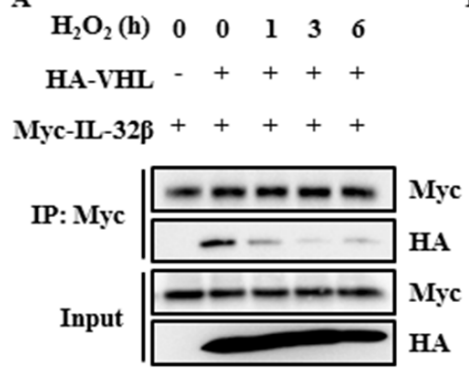

B

VHL

IP: Myc
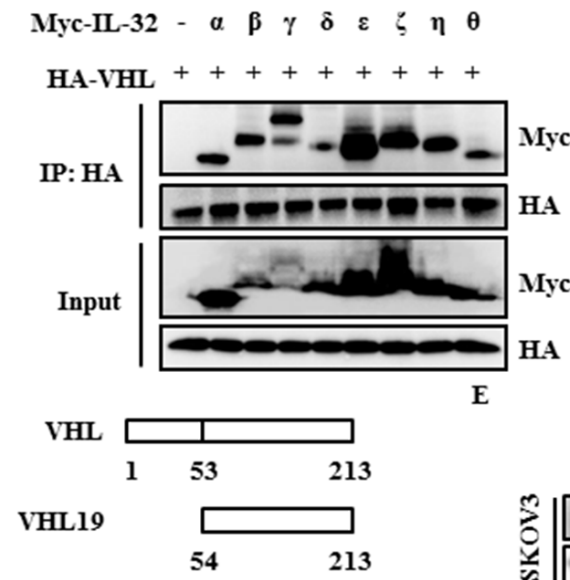

$\begin{array}{llllll}\mathrm{H}_{2} \mathrm{O}_{2}(\mathrm{~h}) & 0 & 0 & 1 & 3 & 6\end{array}$

HA-VHL19 - + + +

$\mathrm{Myc}-\mathrm{IL}-32 \beta+++++$

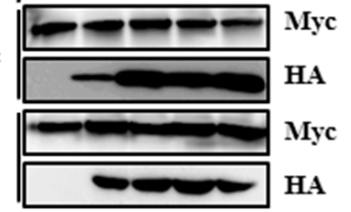

E
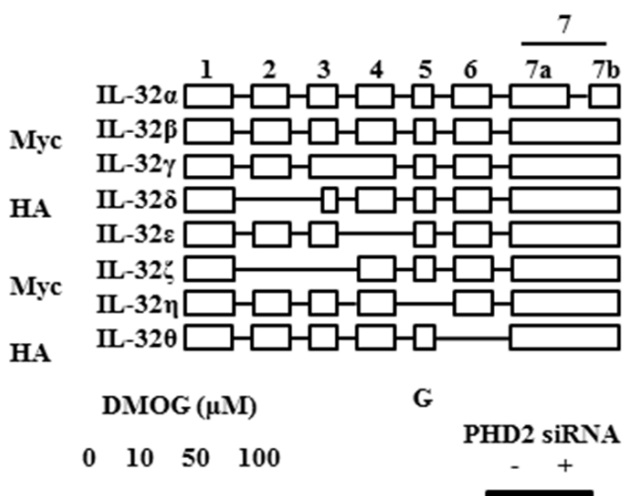

DMOG $(\mu \mathrm{M})$

$\begin{array}{llll}0 & 10 & 50 & 100\end{array}$

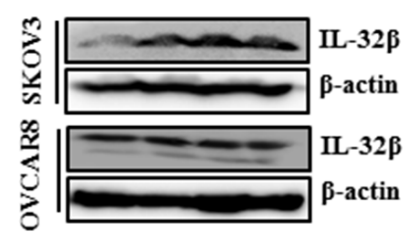

$\mathbf{F}$

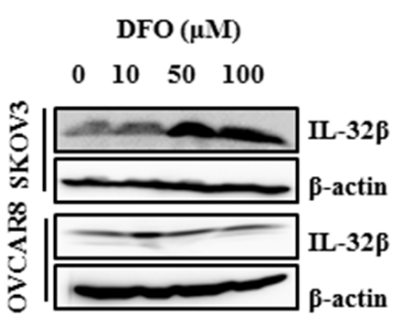

G
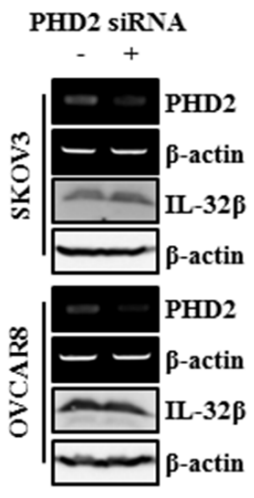

Figure 4: The interaction between IL-32 $\beta$ and VHL is disrupted by ROS. (A) HEK 293T cells were transfected with Myc-IL$32 \beta$ and $\mathrm{HA}-\mathrm{VHL}$, and then treated with $100 \mu \mathrm{M} \mathrm{H}_{2} \mathrm{O}_{2}$ for the indicated times. The cell lysates were immunoprecipitated with anti-Myc antibody and the interaction was examined by immunoblot assay. (B) HEK 293T cells were transfected with the Myc-IL-32 isoforms and HA-VHL. The cell lysates were immunoprecipitated with anti-HA antibody and the interaction was examined by immunoblot assay. (C) HEK 293 T cells were transfected with Myc-IL-32ß, Myc-IL-32 exon 7, and HA-VHL. The cell lysates were immunoprecipitated with anti-HA antibody and the interaction was examined by immunoblot assay. (D) HEK 293T cells were transfected with Myc-IL-32 $\beta$ and HA-VHL19, and then treated with $100 \mathrm{MM} \mathrm{H}_{2} \mathrm{O}_{2}$ for the indicated times. The cell lysates were immunoprecipitated with anti-Myc antibody and the interaction was examined by immunoblot assay. (E) SKOV3 and OVCAR8 cells were treated with DMOG for $24 \mathrm{~h}$. The IL-32 $\beta$ levels were determined by immunoblot assay. (F) SKOV3 and OVCAR8 cells were treated with DFO for 24 h. The IL-32 $\beta$ levels were determined by immunoblot assay. (G) SKOV3 and OVCAR8 cells were transfected with PHD2 siRNA. The PHD2 levels were determined by RT-PCR. The IL-32 $\beta$ levels were determined by immunoblot assay. (H) HEK 293T cells were transfected with Myc-IL-32 $\beta$, HA-VHL wild type (WT), or HA-VHL mutant. The cell lysates were immunoprecipitated with anti-HA antibody and the interaction was examined by immunoblot assay. 
suggest that IL-32 $\beta$, VHL, and PKC $\delta$ form a complex. Under the hypoxic condition, the interaction between VHL and IL-32 $\beta$ or PKC $\delta$ is disrupted, not affecting the interaction between IL-32 $\beta$ and $\mathrm{PKC} \delta$.

\section{IL-32 $\beta$ attenuates $P K C \delta$-induced apoptosis in oxidative stress}

To find out effect of IL-32 $\beta$ and PKC $\delta$ co-expression on apoptosis, proliferation, and migration, SKOV3 cells expressing a low level of IL-32 $\beta$ were induced to express IL-32 $\beta$ and $\mathrm{PKC} \delta$, and OVCAR8 cells expressing a high level of IL-32 $\beta$ were transfected with IL-32 siRNA and PKC $\delta$ siRNA, and then cell apoptosis was examined since $\mathrm{PKC} \delta$ is known to be involved in those functions [23]. $\mathrm{PKC} \delta$ increased the level of cleaved-poly (ADP-ribose) polymerase (PARP) and the activity of caspase-3/7 after $\mathrm{H}_{2} \mathrm{O}_{2}$ treatment. However, co-expression of IL-32 $\beta$ and $\mathrm{PKC} \delta$ reduced the $\mathrm{H}_{2} \mathrm{O}_{2}$-induced apoptosis in the presence of PKC $\delta$, implying that IL-32 $\beta$ attenuates PKC $\delta$-induced
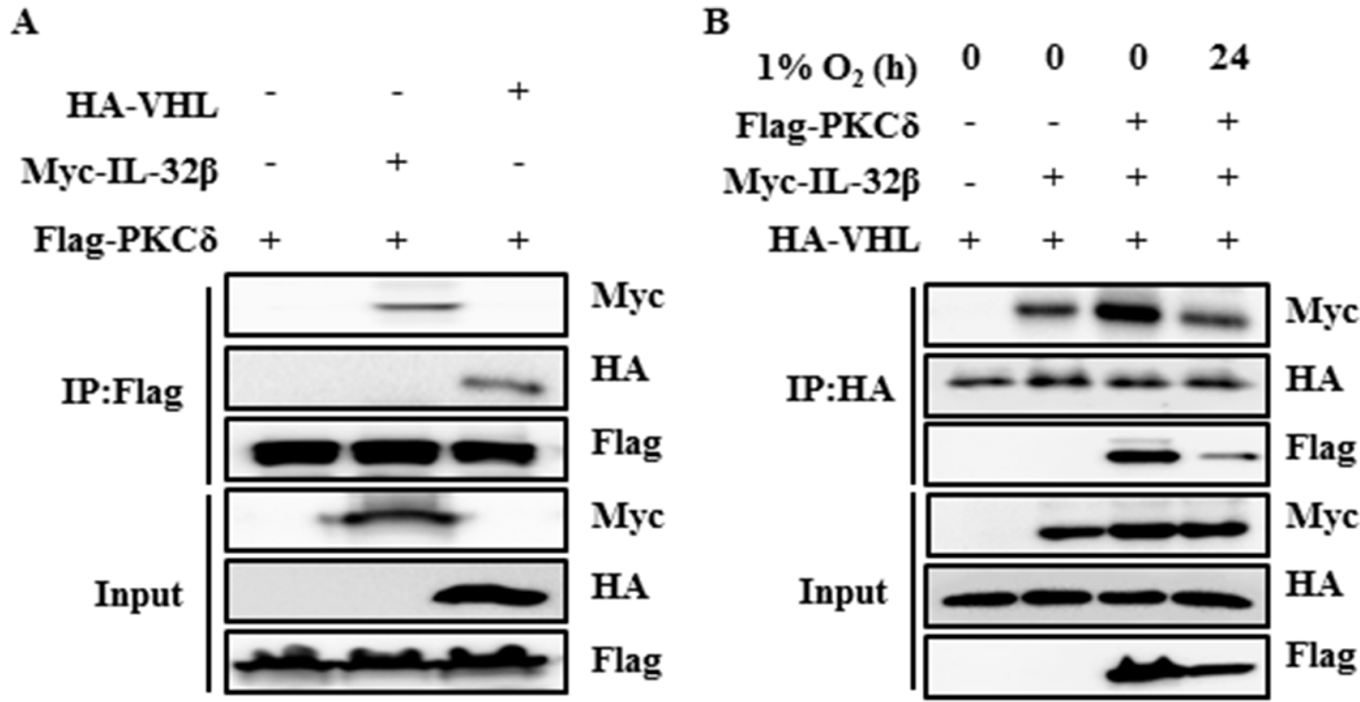

HEK 293T

C

$\begin{array}{rcccc}1 \% \mathrm{O}_{2}(\mathrm{~h}) & 0 & 0 & 6 & 24 \\ \mathrm{Myc}-\mathrm{IL}-32 \beta & - & + & + & + \\ \text { Flag-PKC } \delta & + & + & + & +\end{array}$

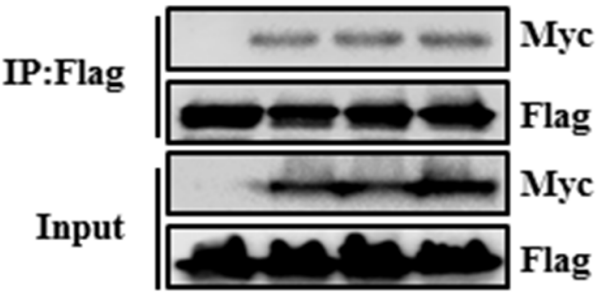

D

$\begin{array}{rcccc}\mathrm{CoCl}_{2}(\mathrm{~h}) & 0 & 0 & 0 & 24 \\ \text { Flag-PKC } \delta & - & - & + & + \\ \mathrm{Myc}-\mathrm{IL}-32 \beta & - & + & + & + \\ \mathrm{HA}-\mathrm{VHL} & + & + & + & +\end{array}$

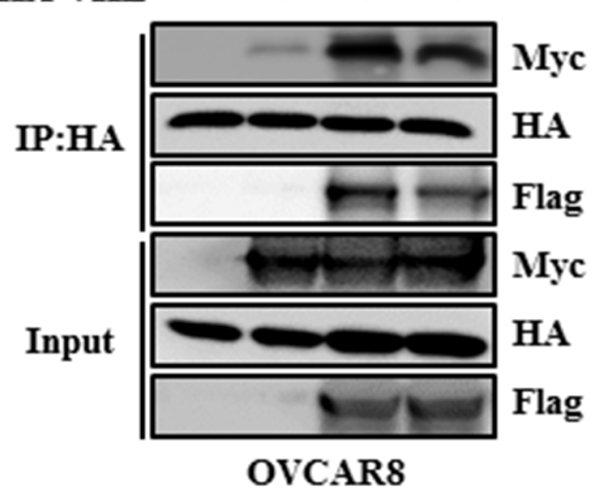

Figure 5: PKC $\delta$ forms a complex with IL-32 $\beta$ and VHL. (A) HEK 293T cells were transfected with Myc-IL-32 $\beta$, HA-VHL, and Flag-PKC. The cell lysates were immunoprecipitated with anti-Flag antibody and the interaction was examined by immunoblot assay. (B) HEK 293T cells were transfected with Myc-IL-32 $\beta$, HA-VHL, and Flag-PKC $\delta$, and then placed in a hypoxia chamber for $24 \mathrm{~h}$. The cell lysates were immunoprecipitated with anti-HA antibody and the interaction was examined by immunoblot assay. (C) HEK 293T cells were transfected with Myc-IL-32 $\beta$ and Flag-PKC $\delta$, and then placed in a hypoxia chamber for $24 \mathrm{~h}$. The cell lysates were immunoprecipitated with anti-Flag antibody and the interaction was examined by immunoblot assay. (D) OVCAR8 cells were transfected with Myc-IL-32 $\beta$, HA-VHL and Flag-PKC $\delta$, and then treated with $150 \mu \mathrm{M} \mathrm{CoCl}_{2}$ for $24 \mathrm{~h}$. The cell lysates were immunoprecipitated with anti-HA antibody and the interaction was examined by immunoblot assay. 
apoptosis under oxidative stress (Figure 6A, 6B). Since $\mathrm{PKC} \delta$ also has an anti-proliferative effect on cancer cells, its effect was examined in the presence of IL-32 $\beta$. The proliferation of SKOV3 and OVCAR8 cells was greatly reduced after $\mathrm{CoCl}_{2}$ treatment, but this was not affected by the co-presence of IL-32 $\beta$ and PKC $\delta$ (Figure 6C). Next, we examined effect of IL-32 $\beta$ and PKC $\delta$ on migration under $\mathrm{CoCl}_{2}$-induced hypoxic conditions. SKOV3 and OVCAR8 cell migration was considerably decreased after $\mathrm{CoCl}_{2}$ treatment, and this effect was not affected by the co-expression of IL-32 $\beta$ and PKC $\delta$ (Figure 6D). These findings imply that the accumulated IL-32 $\beta$ by hypoxiainduced ROS binds to $\mathrm{PKC} \delta$, leads to inhibit $\mathrm{PKC} \delta$ induced apoptosis under oxidative stress without affecting other functions, including proliferation and migration.

\section{DISCUSSION}

Hypoxia-stabilized HIF-1 $\alpha$ binds to hypoxia response elements, leading to the upregulation of several genes to promote survival under low-oxygen conditions. These genes code for enzymes that enhance glycolysis, which allows for ATP synthesis in an oxygen-independent manner [38, 39]. VEGF is a product of one of the HIF$1 \alpha$-induced genes, which promotes angiogenesis and supplies nutrients and oxygen to the tumor mass [40]. In the present study, we identified one more protein (i.e., IL$32 \beta$ ) that is as urgently needed as HIF-1 $\alpha$ under hypoxic and ROS conditions. IL-32 $\beta$ stability was regulated by the post-translational mechanism in SKOV3 and OVCAR8 human ovarian cancer cells. This cytokine was

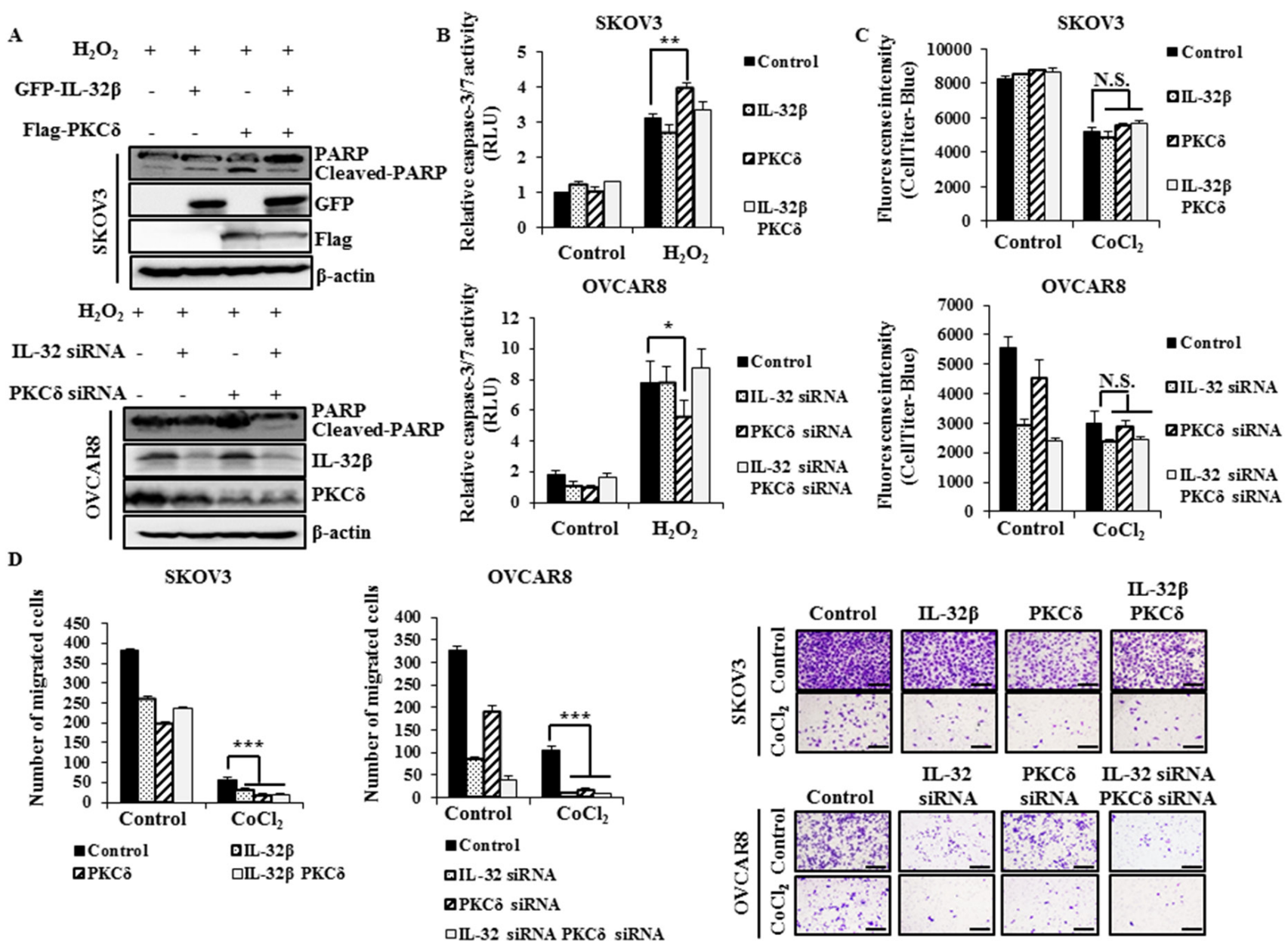

Figure 6: IL-32 $\beta$ prevents PKC $\delta$-induced apoptosis under oxidative stress. (A, B) SKOV3 cells were transfected with GFP-IL$32 \beta$ and Flag-PKC $\delta$ for $24 \mathrm{~h}$, whereas OVCAR 8 cells were transfected with IL-32 siRNA and PKC $\delta$ siRNA for $48 \mathrm{~h}$. The transfected cells were treated with $100 \mu \mathrm{M} \mathrm{H}_{2} \mathrm{O}_{2}$ for $24 \mathrm{~h}$. The caspase-3/7 activity was assessed using a luminescent assay. The cleaved-PARP levels were determined by immunoblot assay. (C) SKOV3 cells were transfected with GFP-IL-32 $\beta$ and Flag-PKC $\delta$. OVCAR8 cells were transfected with IL-32 siRNA and PKC $\delta$ siRNA, and then treated with $150 \mu \mathrm{M} \mathrm{CoCl}_{2}$ for $24 \mathrm{~h}$. The proliferation was assessed using CellTiter-Blue. (D) SKOV3 cells were transfected with GFP-IL-32 $\beta$ and Flag-PKC $\delta$, whereas OVCAR8 cells were transfected with IL-32 siRNA and PKC $\delta$ siRNA. The transfected cells were seeded onto the upper part of a Transwell chamber in serum-free medium with or without $150 \mu \mathrm{M} \mathrm{CoCl}$. The migrated SKOV3 and OVCAR8 cells were counted after 24 or $48 \mathrm{~h}$ incubation, respectively. Scale bars $=10 \mu \mathrm{m}$. 
continuously synthesized and degraded by ubiquitination under normoxic conditions, but accumulated rapidly following exposure to low oxygen tension or ROS. Since the regulation of IL-32 $\beta$ in some of the ovarian tumor cells is energy-consuming, we infer that tumor cells urgently need IL-32 $\beta$ under the hypoxic and ROS conditions. We revealed that hypoxia- and ROS-stabilized IL-32 $\beta$ prevents $\mathrm{PKC} \delta$-mediated apoptosis, and this would rescue tumor cells from sudden death caused by environmental changes (Figure 7).

Various isoforms of IL-32 are produced by alternative splicing mechanism and there are conflicting observations of either an oncogenic or a tumor suppressive role for IL-32 $[12,41]$. These contradictory results might originate from differences in the IL-32 isoform expressed in tumors analyzed. It is reported that IL-32 $\gamma$ and IL$32 \beta$ induce caspase-8-dependent cell death in HEK293 cells whereas IL-32 $\alpha$ does not, and that the treatment of alternative splicing inhibitor results in the predominant expression of IL-32 $\gamma$ splice variants and cell death in thyroid cancer cell lines [42]. On the other hand, IL-32 $\beta$ itself shows either an oncogenic or a tumor suppressive role. In this study, ROS-induced IL- $32 \beta$ reduced PKC $\delta$ induced apoptosis, however, IL-32 $\beta$ transgenic mice have the increased cytotoxic T lymphocytes and NK cells activity, leads to the inhibition to tumor growth [15]. A plausible explanation about contrary IL-32 $\beta$ function could be that physiological environments such as ROS condition and change of immune system affects IL-32 $\beta$ role.

To find out which E3 ligases are responsible for IL$32 \beta$ ubiquitination, the hypoxia- or ROS-related E3 ligases VHL, CHIP, and Keap1 [20, 29-32] were examined. Among these, only VHL could bind to and ubiquitinate IL-32 $\beta$. Whereas VHL binding to HIF- $1 \alpha$ is dependent on prolyl hydroxylation, the interaction between IL-32 $\beta$ and VHL was not dependent on prolyl hydroxylation of IL-32 $\beta$. As with IL-32 $\beta$, it is known that Aurora kinase
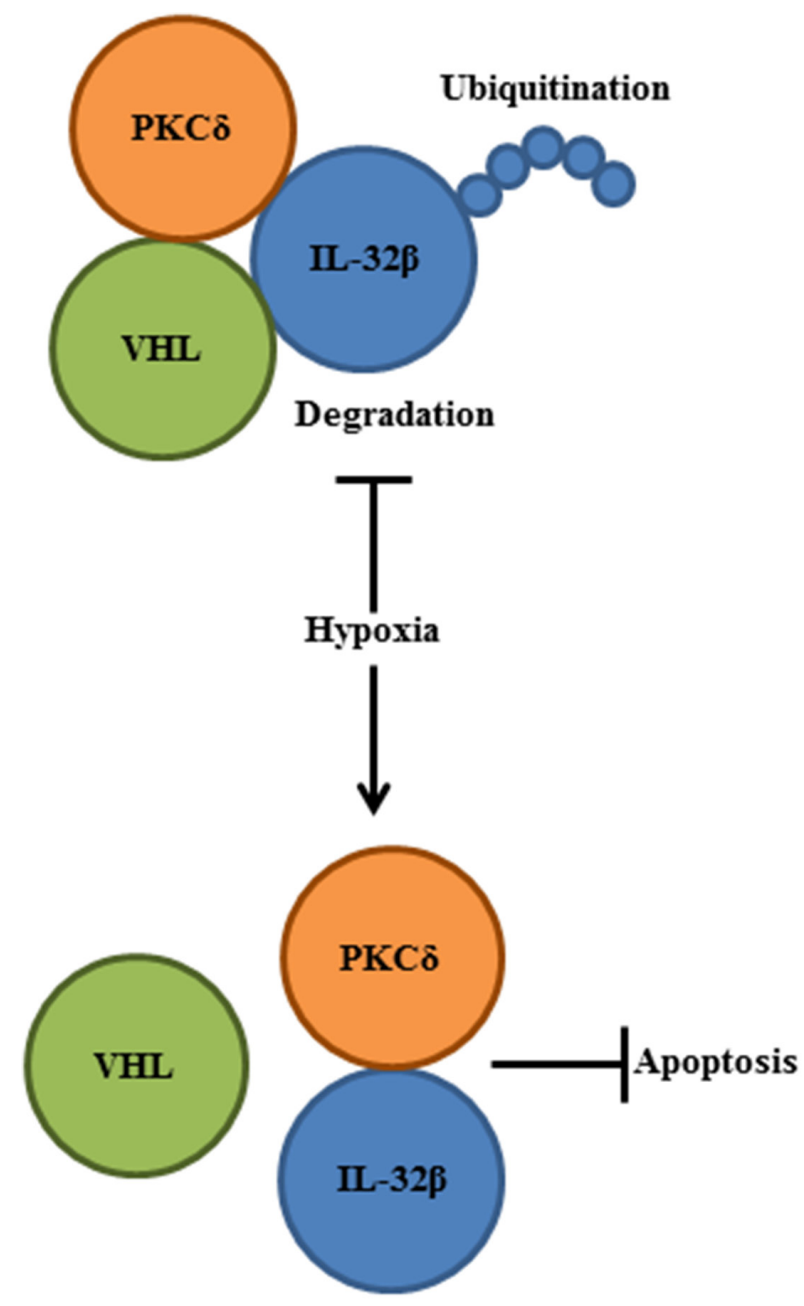

Figure 7: A schematic diagram summarizes IL-32 $\beta$ function in human ovarian cancer cells. Hypoxia-induced ROS disrupted the interaction between IL-32 $\beta$ and VHL, leading to the IL-32 $\beta$ accumulation. The increased IL-32 $\beta$ bound to PKC $\delta$ in the oxidative stress condition and PKC $\delta$-mediated apoptosis was inhibited. 
A is also regulated by VHL in a prolyl hydroxylation independent manner [43]. We have therefore provided one more protein that is a VHL target, but for which binding is hydroxylation independent. On the other hand, Stoehr et al. showed that the inhibition of prolyl hydroxylation by DMOG stabilizes many proteins that have potential function under the hypoxic conditions [44]. Since DMOG treatment stabilized IL-32 $\beta$ (Figure $4 \mathrm{D})$, the prolyl hydroxylation of IL-32 $\beta$ itself could stimulate its degradation under normoxic conditions, but it would not depend on VHL interaction, since we showed that the interaction between VHL and IL-32 $\beta$ was not dependent on IL-32 $\beta$ prolyl hydroxylation. Therefore, we can infer that IL-32 $\beta$ is degraded by two ways under normoxic conditions: prolyl hydroxylation-induced IL-32 $\beta$ degradation, and VHL-mediated degradation in a prolyl hydroxylation-independent manner. On the other hand, since prolyl hydroxylation-induced IL-32 $\beta$ degradation was not observed in OVCAR8 cells (Figure 4D, 4E), this process may need another factor that is absent in OVCAR8 cells.

It is known that PKC $\delta$ interacts with the $\beta$ domain of VHL, but its overall protein levels are not affected by the interaction with VHL $[45,46]$. The interaction of PKC $\delta$ with VHL retains PKC $\delta$ in the cytoplasm, which in turn impairs the association between PKC $\delta$ and the insulin-like growth factor 1 (IGF-I) receptor [37]. Therefore, besides the degradation of binding partners, another effect of the interaction with VHL is the limit of the localization of binding partners. In contrast to inactive PKCs, which are present mainly in the cytosol, activated PKCs are localized at the plasma membrane, the nucleus, and other subcellular compartments [47]. Hypoxic conditions in particular trigger the translocation of $\mathrm{PKC} \delta$ to the endoplasmic reticulum or mitochondria, resulting in oxidative stressinduced apoptosis [24-26, 48]. Since the hypoxic stimulus translocates IL-32 $\beta$ to the mitochondria in breast cancer cells [14], IL-32 $\beta$ could inhibit PKC $\delta$-mediated apoptosis. In turn, hypoxia- and ROS-stabilized IL-32 $\beta$ contributes to cancer cell survival. On the other hand, IL-32 $\beta$ interacts with PKC $\delta$ in the human monocytic cell line U-937, and its interaction shifts the immune reaction from an inflammatory to an anti-inflammatory one by enhancing anti-inflammatory cytokine IL-10 production and inhibiting the secretion of IL- $1 \beta$ and TNF- $\alpha[27,28]$. These findings suggest that IL-32 $\beta$ plays a favorable role in tumor cell survival by affecting the function of both tumor and immune cells.

In conclusion, hypoxia releases IL-32 $\beta$ from ubiquitination-mediated degradation. Subsequently, the increased IL-32 $\beta$ interacts with PKC $\delta$ and results in the inhibition of apoptosis, which can be induced by ROSactivated $\mathrm{PKC} \delta$. In turn, the hypoxia-induced IL-32 $\beta$ is beneficial for tumor cell survival under hypoxic and ROS environments. The limitation of our study is that the effect of IL-32 $\beta$ could not be validated using knockout mice, because this cytokine is not expressed in rodents. Nonetheless, the functions of IL-32 $\beta$ have been and continued to be unveiled with the use of various cancer models.

\section{MATERIALS AND METHODS}

\section{Cell cultures and differentiation}

The IGROV1, SKOV3 and OVCAR8 cells were maintained in RPMI-1640 medium (HyClone Laboratories, UT, USA) containing 10\% heat-inactivated fetal bovine serum (FBS; HyClone Laboratories), whereas the HEK 293T cells were maintained in Dulbecco's modified Eagle's medium (HyClone Laboratories) containing $10 \%$ heat-inactivated FBS. All cells were incubated at $37^{\circ} \mathrm{C}$ in a humidified $5 \% \mathrm{CO}_{2}$ incubator.

\section{Plasmids}

The green fluorescent protein-tagged IL-32 $\beta$ (GFPIL-32 $\beta$ ), Flag-PKC $\delta$, and Myc-IL-32 isoforms and IL-32 $\beta$ expressing plasmids were obtained from Prof. Do-Young Yoon at Konkuk University. HA-Ub was obtained from Prof. Keun Il Kim at Sookmyung Women's University. HA-VHL and HA-VHL19 were obtained from Prof. Jae Whan Song at Yeonsei University. The HA-VHL Y98N and W117R were purchased from Addgene (Cambridge, MA, USA). Truncated mutants of IL-32 were prepared by PCR and subcloned into the EcoRI-SalI sites of pEGFPN2, or the EcoRI-XhoI sites of the Myc-pcDNA3.1 mammalian expression vector. VHL S111D was prepared by PCR and subcloned into the EcoRI-XhoI sites of the HA-pcDNA3 mammalian expression vector.

\section{Antibodies}

The following antibodies were used: anti-IL-32 antibody (provided by Prof. Do-Young Yoon), anti- $\beta$-actin antibody, anti-HA antibody, anti-GFP antibody, anti-PKC $\delta$ antibody (Santa Cruz Biotechnology, Santa Cruz, CA, USA) anti-Flag antibody (Sigma Aldrich, St. Louis, MO, USA), anti-Myc-Tag antibody, and anti-PARP antibody (Cell Signaling Technology, Danvers, MA, USA).

\section{Chemicals}

The following chemicals were obtained from commercial sources: $\mathrm{CoCl}_{2}, \mathrm{CHX}$, MG-132, NAC, pepstatin $\mathrm{A}, \mathrm{H}_{2} \mathrm{O}_{2}$, DMOG, and DFO (Sigma Aldrich).

\section{RNA interference and transfection}

For the RNA interference assay, IL-32and VHL-specific siRNA oligonucleotides were purchased from Samchully Pharmaceuticals (Seoul, Korea). The following sequences were used for the 
construction of the siRNAs: IL-32 siRNA forward 5'-GCUCUCUGUCAGAGCUCUU-3' and reverse 5'-AAGAGCUCUGACAGAGAGC-3'; and VHL siRNA forward 5'-CCACAGCUACCGAGUGUAUTT-3' and reverse 5'-AUACACUCGGUAGCUGUGGTT-3'. CHIP siRNA, Keap1 siRNA and PHD2 siRNA were purchased from Santa Cruz Biotechnology. PKC $\delta$ siRNA was purchased from Bioneer (Seoul, Korea). The cells were transfected with $10 \mathrm{nM}$ of siRNA using RNAiMAX (Invitrogen, Carlsbad, CA, USA).

\section{Immunoblot analyses}

The cell lysates were prepared after transfection with plasmids or siRNA and mixed with $5 \times$ sodium dodecyl sulfate (SDS) sample buffer. The mixed samples were heated at $99^{\circ} \mathrm{C}$ for $10 \mathrm{~min}$ and separated electrophoretically on a SDS-polyacrylamide gel. Subsequently, the proteins were transferred onto a $0.45-\mu \mathrm{m}$ nitrocellulose membrane (GE Healthcare, Buckinghamshire, UK) for $2 \mathrm{~h}$. The membrane was blocked for $30 \mathrm{~min}$ at room temperature with 5\% skim milk (Invitrogen) and subsequently incubated with primary antibody overnight at $4^{\circ} \mathrm{C}$. Then, the membrane was incubated with an anti-mouse or anti-rabbit IgG antibody conjugated to horseradish peroxidase (Assay Designs, Ann Arbor, MI, USA) at room temperature for $2 \mathrm{~h}$. The proteins were visualized using an enhanced chemiluminescent substrate (Thermo Fisher Scientific, Logan, MA, USA) and analyzed using the LAS3000 luminescent image analyzer (Fuji Film, Tokyo, Japan). The protein bands were quantified using ImageJ software (National Institutes of Health, Bethesda, MD, USA).

\section{Immunoprecipitation assay}

The HEK 293T and OVCAR8 cells were transfected with plasmids for $24 \mathrm{~h}$ and then treated with chemicals. The cell lysates were prepared using cell immunoprecipitation lysis buffer $(50 \mathrm{mM}$ Tris- $\mathrm{HCl}(\mathrm{pH}$ $8.0), 150 \mathrm{mM} \mathrm{NaCl}, 5 \mathrm{mM}$ ethylenediaminetetraacetic acid, $250 \mathrm{mM}$ phenylmethylsulfonyl fluoride, 1\% NP-40) containing a proteinase inhibitor cocktail. The cell lysates were incubated with antibody for $2 \mathrm{~h}$ at room temperature, and then protein-G agarose beads were added. The entire lysates were centrifuged after $2 \mathrm{~h}$ incubation, and then washed four times with washing buffer.

\section{RT-PCR}

Total RNA samples were prepared from SKOV3 and OVCAR8 cells, using the extraction reagent RNAiso Plus (TaKaRa, Tokyo, Japan). The prepared total RNAs were reverse-transcribed using RevertAid reverse transcriptase (Thermo Fisher Scientific) at $42^{\circ} \mathrm{C}$ for $1 \mathrm{~h}$. PCR was performed to amplify the mRNAs that encode IL-32 isoforms, $\beta$-actin, VEGF, VHL, CHIP, Keap1, and PHD2 using the following appropriate primer pairs: IL-32 forward 5'-ATGTGCTTCCCGAAGGTCCTC-3' and reverse 5'-TCATTTTGAGGATTGGGGTTC-3'; $\beta$-actin forward 5'-GTGGGGCGCCCCAGGCACCA-3' and reverse 5'-CTCCTTAATGTCACGCACGAT-3'; VEGF forward 5'-ATGAACTTTCTGCTGTCTTG-3' and reverse 5'-CCGCCTCGGCTTGTCACATCTGC-3'; VHL forward 5'-GAGGTCACCTTTGGCTCTTCA-3' and reverse 5'-CCAGATCTTCGTAGAGCGACC-3'; CHIP forward 5'-GTGATCACCCGGAACCCG-3' and reverse 5'-GCGCTTCTTCTTCGCGATTC-3'; Keap1 forward 5'-CATCCACCCTAAGGTCATGGA-3' and reverse 5'-GACAGGTTGAAGAACTCCTCC-3' and PHD2 forward 5'-GAAGGCAAAGCCCAGTTTGCT-3' and reverse 5'-CGTGCTCTCTCATCTGCATCAA-3'. Real-time PCR was performed with Maxima SYBR Green/ROX qPCR master mix (Thermo Fisher Scientific) to amplify the mRNAs that encode IL-32 $\beta$, IL-32 $\gamma$, and glyceraldehyde 3-phosphate dehydrogenase (GAPDH), using the following appropriate primer pairs: IL-32 $\beta$ forward 5'-CAGGGGAGATACCATGATCG-3' and reverse 5'-ACGGACTAATACGGCAACAGA-3'; IL-32 $\gamma$ forward 5'-TGACATGAAGAAGCTGAAGGC-3' and reverse 5'-CATGACCTTGTCACAAAAGCTC-3'; and GAPDH forward 5'-G TGTTCCTACCCCCAATGTGT-3' and reverse 5'-ATTGTCATACCAGGAAATGAGCTT-3'.

\section{Activity assay}

The Caspase-Glo 3/7 assay (Promega, Madision, WI, USA) was carried out according to the manufacturer's instruction. The assay is based on the release of aminoluciferin as a result of active caspase- $3 / 7$ cleaving the luminogenic substrate containing the DEVD amino acid sequence.

\section{Proliferation assay}

Cell proliferation was evaluated using the CellTiterBlue assay (Promega). Cells were seeded on 48-well plates and incubated for $24 \mathrm{~h}$. Then, the cells were treated with $\mathrm{CoCl}_{2}$ for $24 \mathrm{~h}$. After washing with PBS, diluted CellTiter-Blue reagent was added directly to each well and the plates were incubated at $37^{\circ} \mathrm{C}$ for $1 \mathrm{~h}$. The reagent was transferred to 96 -well plates and, the fluorescence was measured at 560/590 $\mathrm{nm}$.

\section{In vitro migration assay}

Cell migration was assessed in a 24-well plate Transwell system (Corning, Corning, MD, USA). Each $8-\mu \mathrm{m}$ Transwell insert was seeded with $100 \mu \mathrm{L}$ of SKOV3 or OVCAR8 cells in serum-free RPMI-1640 medium with or without $\mathrm{CoCl}_{2}$, and the lower chamber was filled with $500 \mu \mathrm{L}$ RPMI-1640 medium containing 10\% FBS with or without $\mathrm{CoCl}_{2}$. The cells were incubated for 24 or 48 $\mathrm{h}$, respectively. Images of the membrane were taken in 
three random fields per chamber, and the total number of migrated cells was counted.

\section{Statistical analyses}

Statistical analyses were performed by a paired Student's t-test and one-way factorial analysis of variance. The Scheffe and Bonferroni tests were also performed. Values of $* \mathrm{p}<0.05, * * \mathrm{p}<0.01$, and $* * * \mathrm{p}<0.001$ were considered benchmarks of significant differences. Data are presented as the means \pm standard deviation.

\section{Abbreviations}

2OG, 2-oxoglutarate; CC-RCC, clear cell renal cell carcinoma; CHIP, carboxyl terminus of HSP70interacting protein; $\mathrm{CHX}$, cyclohexamide; $\mathrm{CoCl} 2$, cobalt chloride II; DAG, diacylglycerol; DFO, desferrioxamine; DMEM, Dulbecco's modified Eagle's medium; DMOG, dimethyloxaloylglycine; FBS, fetal bovine serum; FIH, factor inhibiting HIF; H2O2, hydrogen peroxide; HIF$1 \alpha$, hypoxia-inducible factor-1alpha; HRE, hypoxiaresponse element; IGF-I, insulin-like growth factor 1; IL, interleukin; IP, Immunoprecipitation; Keap1, Kelch-like ECH-associated protein 1; NAC, N-acetyl-cysteine; NF$\kappa \mathrm{B}$, nuclear factor kappa-light-chain-enhancer of activated B cells; NK cells, natural killer cells; Nrf-2, nuclear factor erythroid 2-related factor 2; PHD, prolyl hydroxylase; PKC, protein kinase C; ROS, reactive oxygen species; SD, standard deviations; SDS, sodium dodecyl sulfate; siRNA, small interfering RNA; STAT3, signal transducer and activator of transcription 3; $\mathrm{TNF} \alpha$, tumor necrosis factor alpha; VEGF, vascular endothelial growth factor; VHL, von Hippel-Lindau.

\section{CONFLICTS OF INTEREST}

The authors declare no conflicts of interest.

\section{FUNDING}

This work was supported by the National Research Foundation of Korea (NRF) grant funded by the Korean government (MSIP) [NRF-2016R1A2B2011683, NRF2015M3A9B6027818 2016R1A5A1011974].

\section{REFERENCES}

1. Choi JD, Bae SY, Hong JW, Azam T, Dinarello CA, Her E, Choi WS, Kim BK, Lee CK, Yoon DY, Kim SJ, Kim $\mathrm{SH}$. Identification of the most active interleukin-32 isoform. Immunology. 2009; 126:535-42.

2. Netea MG, Azam T, Lewis EC, Joosten LA, Wang M, Langenberg D, Meng X, Chan ED, Yoon DY, Ottenhoff T, Kim SH, Dinarello CA. Mycobacterium tuberculosis induces interleukin-32 production through a caspase- 1/
IL-18/interferon- $\gamma$-dependent mechanism. PLoS Med. 2006; $3: \mathrm{e} 277$.

3. Joosten LA, Heinhuis B, Netea MG, Dinarello CA. Novel insights into the biology of interleukin-32. Cell Mol Life Sci. 2013; 70:3883-92.

4. Kim MS, Kang JW, Park YS, Lee DH, Bak Y, Kwon T, Yoon DY. IL-32 $\theta$ inhibits monocytic differentiation of leukemia cells by attenuating expression of transcription factor PU.1. Oncotarget. 2015; 6:4394-405. https://doi. org/10.18632/oncotarget.3013.

5. Kobayashi H, Lin PC. Molecular characterization of IL-32 in human endothelial cells. Cytokine. 2009; 46:351-8.

6. Nishida A, Andoh A, Inatomi O, Fujiyama Y. Interleukin-32 expression in the pancreas. J Biol Chem. 2009; 284:17868-76.

7. Seo EH, Kang J, Kim KH, Cho MC, Lee S, Kim HJ, Kim JH, Kim EJ, Park DK, Kim SH, Choi YK, Kim JM, Hong JT, et al. Detection of expressed IL-32 in human stomach cancer using ELISA and immunostaining. J Microbiol Biotechnol. 2008; 18:1606-12.

8. Kang YH, Park MY, Yoon DY, Han SR, Lee CI, Ji NY, Myung PK, Lee HG, Kim JW, Yeom YI, Jang YJ, Ahn DK, Kim JW, et al. Dysregulation of overexpressed IL-32 $\alpha$ in hepatocellular carcinoma suppresses cell growth and induces apoptosis through inactivation of NF- $\mathrm{BB}$ and Bcl2. Cancer Lett. 2012; 318:226-33.

9. Oh JH, Cho MC, Kim JH, Lee SY, Kim HJ, Park ES, Ban JO, Kang JW, Lee DH, Shim JH, Han SB, Moon DC, Park YH, et al. IL-32 $\gamma$ inhibits cancer cell growth through inactivation of NF- $\mathrm{kB}$ and STAT3 signals. Oncogene. 2011; 30:3345-59.

10. Yun HM, Park KR, Kim EC, Han SB, Yoon DY, Hong JT. IL-32 $\alpha$ suppresses colorectal cancer development via TNFR1-mediated death signaling. Oncotarget. 2015; 6:9061-72. https://doi.org/10.18632/oncotarget.3197.

11. Park ES, Yoo JM, Yoo HS, Yoon DY, Yun YP, Hong J. IL-32 $\gamma$ enhances TNF- $\alpha$-induced cell death in colon cancer. Mol Carcinog. 2014; 53:E23-35.

12. Lee J, Kim KE, Cheon S, Song JH, Houh Y, Kim TS, Gil M, Lee KJ, Kim S, Kim D, Hur DY, Yang Y, Bang SI, et al. Interleukin-32 $\alpha$ induces migration of human melanoma cells through downregulation of E-cadherin. Oncotarget. 2016; 7:65825-36. https://doi.org/10.18632/oncotarget.11669.

13. Park JS, Choi SY, Lee JH, Lee M, Nam ES, Jeong AL, Lee S, Han S, Lee MS, Lim JS, Yoon DY, Kwon Y, Yang Y. Interleukin-32 $\beta$ stimulates migration of MDA-MB-231 and MCF-7cells via the VEGF-STAT3 signaling pathway. Cell Oncol (Dordr). 2013; 36:493-503.

14. Park JS, Lee S, Jeong AL, Han S, Ka HI, Lim JS, Lee MS, Yoon DY, Lee JH, Yang Y. Hypoxia-induced IL-32 $\beta$ increases glycolysis in breast cancer cells. Cancer Lett. 2015; 356:800-8.

15. Yun HM, Oh JH, Shim JH, Ban JO, Park KR, Kim JH, Lee DH, Kang JW, Park YH, Yu D, Kim Y, Han SB, Yoon DY, 
et al. Antitumor activity of IL-32 $\beta$ through the activation of lymphocytes, and the inactivation of NF- $\mathrm{KB}$ and STAT3 signals. Cell Death Dis. 2013; 4:e640.

16. Lisztwan J, Imbert G, Wirbelauer C, Gstaiger M, Krek W. The von Hippel-Lindau tumor suppressor protein is a component of an E3 ubiquitin-protein ligase activity. Genes Dev. 1999; 13:1822-33.

17. Groulx I, Lee S. Oxygen-dependent ubiquitination and degradation of hypoxia-inducible factor requires nuclearcytoplasmic trafficking of the von Hippel-Lindau tumor suppressor protein. Mol Cell Biol. 2002; 22:5319-36.

18. Snell CE, Turley H, McIntyre A, Li D, Masiero M, Schofield CJ, Gatter KC, Harris AL, Pezzella F. Proline-hydroxylated hypoxia-inducible factor $1 \alpha(\mathrm{HIF}-1 \alpha)$ upregulation in human tumours. PLoS One. 2014; 9:e88955.

19. Melillo G. (2014). Hypoxia and cancer: biological implications and therapeutic opportunities. (New York: Humana Press).

20. Gossage L, Eisen T, Maher ER. VHL, the story of a tumour suppressor gene. Nat Rev Cancer. 2015; 15:55-64.

21. Arsenault PR, Heaton-Johnson KJ, Li LS, Song D, Ferreira VS, Patel N, Master SR, Lee FS. Identification of prolyl hydroxylation modifications in mammalian cell proteins. Proteomics. 2015; 15:1259-67.

22. Hewitson KS, McNeill LA, Riordan MV, Tian YM, Bullock AN, Welford RW, Elkins JM, Oldham NJ, Bhattacharya S, Gleadle JM, Ratcliffe PJ, Pugh CW, Schofield CJ. Hypoxiainducible factor (HIF) asparagine hydroxylase is identical to factor inhibiting HIF (FIH) and is related to the cupin structural family. J Biol Chem. 2002; 277:26351-5.

23. Griner EM, Kazanietz MG. Protein kinase C and other diacylglycerol effectors in cancer. Nat Rev Cancer. 2007; 7:281-94.

24. Cosentino-Gomes D, Rocco-Machado N, Meyer-Fernandes JR. Cell signaling through protein kinase $\mathrm{C}$ oxidation and activation. Int J Mol Sci. 2012; 13:10697-721.

25. Gomel R, Xiang C, Finniss S, Lee HK, Lu W, Okhrimenko $\mathrm{H}$, Brodie $\mathrm{C}$. The localization of protein kinase $\mathrm{C} \delta$ in different subcellular sites affects its proapoptotic and antiapoptotic functions and the activation of distinct downstream signaling pathways. Mol Cancer Res. 2007; 5:627-39.

26. Qi X, Mochly-Rosen D. The PKC $\delta-A b l$ complex communicates ER stress to the mitochondria - an essential step in subsequent apoptosis. J Cell Sci. 2008; 121:804-13.

27. Kang JW, Park YS, Kim MS, Lee DH, Bak Y, Ham SY, Park SH, Hong JT, Yoon DY. Interleukin (IL)-32 $\beta$ mediated CCAAT/enhancer-binding protein $\alpha(\mathrm{C} / \mathrm{EBP} \alpha)$ phosphorylation by protein kinase $\mathrm{C} \delta(\mathrm{PKC} \delta)$ abrogates the inhibitory effect of $\mathrm{C} / \mathrm{EBP} \alpha$ on IL-10 production. J Biol Chem. 2013; 288:23650-8.

28. Kang JW, Park YS, Lee DH, Kim MS, Bak Y, Park SH, Ham SY, Yang Y, Hong JT, Yoon DY. Interleukin-32 $\delta$ interacts with IL-32 $\beta$ and inhibits IL-32 $\beta$-mediated IL-10 production. FEBS Lett. 2013.

29. Tsvetkov P, Adamovich Y, Elliott E, Shaul Y. E3 ligase STUB1/CHIP regulates NAD(P)H:quinone oxidoreductase 1 (NQO1) accumulation in aged brain, a process impaired in certain Alzheimer disease patients. J Biol Chem. 2011; 286:8839-45.

30. Murata S, Minami Y, Minami M, Chiba T, Tanaka K. CHIP is a chaperone-dependent E3 ligase that ubiquitylates unfolded protein. EMBO Rep. 2001; 2:1133-8.

31. Sporn MB, Liby KT. NRF2 and cancer: the good, the bad and the importance of context. Nat Rev Cancer. 2012; 12:564-71.

32. Ashino T, Yamamoto M, Numazawa S. Nrf2/Keap1 system regulates vascular smooth muscle cell apoptosis for vascular homeostasis: role in neointimal formation after vascular injury. Sci Rep. 2016; 6:26291.

33. Bak Y, Kang JW, Kim MS, Park YS, Kwon T, Kim S, Hong J, Yoon DY. IL-320 downregulates CCL5 expression through its interaction with PKC $\delta$ and STAT3. Cell Signal. 2014; 26:3007-15.

34. Minervini G, Mazzotta GM, Masiero A, Sartori E, Corra $\mathrm{S}$, Potenza E, Costa R, Tosatto SC. Isoform-specific interactions of the von Hippel-Lindau tumor suppressor protein. Sci Rep. 2015; 5:12605.

35. Okuda H, Hirai S, Takaki Y, Kamada M, Baba M, Sakai N, Kishida T, Kaneko S, Yao M, Ohno S, Shuin T. Direct interaction of the $\beta$-domain of VHL tumor suppressor protein with the regulatory domain of atypical PKC isotypes. Biochem Biophys Res Commun. 1999; 263:491-7.

36. Nyhan MJ, O'Sullivan GC, McKenna SL. Role of the VHL (von Hippel-Lindau) gene in renal cancer: a multifunctional tumour suppressor. Biochem Soc Trans. 2008; 36:472-8.

37. Razorenova OV, Finger EC, Colavitti R, Chernikova SB, Boiko AD, Chan CK, Krieg A, Bedogni B, LaGory E, Weissman IL, Broome-Powell M, Giaccia AJ. VHL loss in renal cell carcinoma leads to up-regulation of CUB domaincontaining protein 1 to stimulate $\mathrm{PKC} \delta$-driven migration. Proc Natl Acad Sci U S A. 2011; 108:1931-6.

38. Eales KL, Hollinshead KE, Tennant DA. Hypoxia and metabolic adaptation of cancer cells. Oncogenesis. 2016; 5:e190.

39. Solaini G, Baracca A, Lenaz G, Sgarbi G. Hypoxia and mitochondrial oxidative metabolism. Biochim Biophys Acta. 2010; 1797:1171-7.

40. Krock BL, Skuli N, Simon MC. Hypoxia-induced angiogenesis: good and evil. Genes Cancer. 2011; 2:1117-33. https://doi.org/10.1177/1947601911423654.

41. Bak Y, Kwon T, Bak IS, Hong J, Yu DY, Yoon DY. IL-32 $\theta$ inhibits stemness and epithelial-mesenchymal transition of cancer stem cells via the STAT3 pathway in colon cancer. Oncotarget. 2016; 7:7307-17. https://doi.org/10.18632/ oncotarget. 7007 . 
42. Heinhuis B, Plantinga TS, Semango G, Kusters B, Netea MG, Dinarello CA, Smit JWA, Netea-Maier RT, Joosten LAB. Alternatively spliced isoforms of IL-32 differentially influence cell death pathways in cancer cell lines. Carcinogenesis. 2016; 37:197-205.

43. Dere R, Perkins AL, Bawa-Khalfe T, Jonasch D, Walker CL. $\beta$-catenin links von Hippel-Lindau to aurora kinase A and loss of primary cilia in renal cell carcinoma. J Am Soc Nephrol. 2015; 26:553-64.

44. Stoehr A, Yang Y, Patel S, Evangelista AM, Aponte A, Wang G, Liu P, Boylston J, Kloner PH, Lin Y, Gucek M, Zhu J, Murphy E. Prolyl hydroxylation regulates protein degradation, synthesis, and splicing in human induced pluripotent stem cell-derived cardiomyocytes. Cardiovasc Res. 2016; 110:346-58.
45. Zhang Q, Yang H. The Roles of VHL-Dependent Ubiquitination in Signaling and Cancer. Front Oncol. 2012; $2: 35$.

46. Iturrioz X, Durgan J, Calleja V, Larijani B, Okuda H, Whelan R, Parker PJ. The von Hippel-Lindau tumoursuppressor protein interaction with protein kinase $\mathrm{C} \delta$. Biochem J. 2006; 397:109-20.

47. Rimessi A, Rizzuto R, Pinton P. Differential recruitment of PKC isoforms in HeLa cells during redox stress. Cell Stress Chaperones. 2007; 12:291-8.

48. Majumder PK, Mishra NC, Sun X, Bharti A, Kharbanda $\mathrm{S}$, Saxena S, Kufe D. Targeting of protein kinase $\mathrm{C} \delta$ to mitochondria in the oxidative stress response. Cell Growth Differ. 2001; 12:465-70. 